\title{
PARP-1 Val762Ala polymorphism is associated with reduced risk of non-Hodgkin lymphoma in Korean males
}

Xue Mei Jin ${ }^{1,2}$, Hee Nam Kim ${ }^{1}, \|-K w o n$ Lee ${ }^{1}$, Kyeong-Soo Park ${ }^{1,5}$, Hyeoung-Joon Kim ${ }^{1,3}$, Jin-Su Choi ${ }^{4}$, Sang Woo Juhng ${ }^{2}$, Chan Choi ${ }^{1,2^{*}}$

\begin{abstract}
Background: Poly(ADP-ribose) polymerase-1 (PARP-1) is a nuclear enzyme that plays a role in DNA repair, differentiation, proliferation, and cell death. The polymorphisms of PARP-1 have been associated with the risk of various carcinomas, including breast, lung, and prostate. We investigated whether PARP-1 polymorphisms are associated with the risk of non-Hodgkin lymphoma (NHL).
\end{abstract}

Methods: Subjects from a Korean population consisting of $573 \mathrm{NHL}$ patients and 721 controls were genotyped for 5 PARP-1 polymorphisms (Asp81Asp, Ala284Ala, Lys352Lys, IVS13+118A>G, and Val762Ala) using High Resolution Melting polymerase chain reaction (PCR) and an automatic sequencer.

Results: None of the 5 polymorphisms were associated with overall risk for NHL. However, the Val762Ala polymorphism was associated with reduced risk for $\mathrm{NHL}$ in males [odds ratio (OR), $0.62 ; 95 \%$ confidence interval (Cl), 0.41-0.93 for CC genotype and OR, 0.84; 95\% Cl, 0.60-1.16 for TC genotype] with a trend toward a gene dose effect ( $p$ for trend, 0.02). The Asp81Asp ( $p$ for trend, 0.04) and Lys352Lys ( $p$ for trend, 0.03) polymorphisms revealed the same trend. In an association study of PARP-1 haplotypes, the haplotype-ACAAC was associated with decreased risk of $\mathrm{NHL}$ in males $(\mathrm{OR}, 0.75 ; 95 \% \mathrm{Cl}, 0.59-0.94)$.

Conclusion: The present data suggest that Val762Ala, Asp81Asp, and Lys352Lys polymorphisms and the haplotypeACAAC in PARP-1 are associated with reduced risk of NHL in Korean males.

\section{Background}

Non-Hodgkin lymphoma (NHL) is the most common hematologic malignancy worldwide. It represents $4 \%$ of cancers, and is the fifth commonly diagnosed cancer in the United States [1]. Its rates are over 10/100,000 in the United States, Australia, and Western Europe, while less than 5/100,000 in Southern and Eastern Asia [2].

PARP-1 is a nuclear enzyme that catalyzes the poly (ADP-ribosyl)ation of target proteins in response to DNA damage; it is involved in DNA repair, cell death, proliferation, genome integrity, and modulation of gene transcription $[3,4]$. PARP-1 is involved in base excision reaction, which repairs DNA damage induced by

\footnotetext{
*Correspondence: cchoi@chonnam.ac.kr
${ }^{1}$ Genome Research Center for Hematopoietic Diseases, Chonnam National

* Correspondence: cchoi@chonnam.ac.kr
'Genome Research Center for Hematopoietic Diseases, Chonnam National University Hwasun Hospital, 160, Ilsim-ni, Hwasun-eup, Hwasun-gun, Chonnam, 519-809, Republic of Korea
}

(c) 2010 Jin et al; licensee BioMed Central Ltd. This is an Open Access article distributed under the terms of the Creative Commons Attribution License (http://creativecommons.org/licenses/by/2.0), which permits unrestricted use, distribution, and reproduction in any medium, provided the original work is properly cited. ionizing radiation. In addition, PARP-1 activation mediates apoptosis through the induction of translocation of apoptosis-inducing factor from the mitochondria to the nucleus [5].

The effect of PARP-1 on carcinogenesis is still unclear and controversial. PARP-1 activation has been reported to inhibit carcinogenesis by activation of DNA repair system [6-13]. Parp deficiencies have enhanced tumorigenesis and widened the tumor spectrum in $p 53$-deficient mice [10]. Treatment with the alkylating agent, azoxymethane, enhanced the frequency of tumor development in the colon and liver of Parp $-1^{-1-}$ mice [9]. Studies have demonstrated that PARP-1 Val762Ala polymorphism is associated with an increased risk of carcinomas, including prostate [8], esophagus [7], lung [12], stomach [11], breast [13], and urinary bladder [6]. 
In contrast, others have reported that inhibition or the absence of PARP-1 is associated with reduced risk of malignancy by inducing tumor cell apoptosis [14-18]. Loss of Parp-1 has increased tumor latency in $p 53$-deficient mice [14]. Parp- $1^{-1-}$ mice displayed a diminished susceptibility to skin carcinogenesis compared with Parp $-1^{+/+}$mice after treatment with 7,12-dimethylbenz [a]-anthracene and 12-O-tetra-decanoyl-phorbol13-acetate [17]. PARP-1 polymorphisms have been associated with reduced risk of malignancy in several case-control studies $[15,16,18]$. However, others have also proposed that PARP-1 has no effects on tumor development $[19,20]$. Parp- ${ }^{-1-}$ mice did not demonstrate an increased incidence of tumor formation after either 4-nitroso-quinoline or 2-amino-3-methylimidazo treatment [19]. In a case-control study in Connecticut women, the risk of NHL was not associated with PARP-1 Val762Ala polymorphism [20].

Although many studies have searched for the association between PARP-1 polymorphisms and the risk of malignancy, the results are inconsistent in different organs and in different ethnic groups. We performed a population-based, case-control study to identify the association between PARP-1 polymorphisms and NHL risk in Korean subjects.

\section{Methods}

\section{Study population}

This case-control study included NHL patients $(\mathrm{n}=573)$ and cancer-free controls $(\mathrm{n}=721)$. All cases and controls were unrelated Korean individuals; the cases were adults (median age at diagnosis \pm S.D $55.0 \pm 14.6$ years, range 15.0-90.0 years), histologically diagnosed with NHL between 1997 and 2006 at Chonnam National University Hospital (Gwangju, Korea) or Chonnam National University Hwasun Hospital (Hwasun, Korea) [21]. Lymph nodes or extranodal tissues were obtained and histologically diagnosed according to the World Health Organization (WHO) classification [22]. A staging workup included physical examination, laboratory examination, computed tomography scan, bone marrow biopsy, and lumbar puncture. Stages were defined according to the Ann Arbor system [23]. Types of NHL included diffuse large B-cell lymphomas $(\mathrm{n}=330)$, T-cell lymphomas $(n=122)$, and other lymphomas $(n=121)$. The controls were frequency matched to patients by age within 5 years, sex, and county of residence. All of the healthy controls have no history of cancer (427 males, 304 females; median age \pm S.D. $56.0 \pm 15.3$ years, range 17.0-82.5 years) (Table 1). All cases and controls provided informed consent for study participation. The study was approved by the Institutional Review Board of the Chonnam National University Hwasun Hospital in Hwasun, Korea.
Table 1 Frequency distribution of selected characteristics of study subjects According to case-control status

\begin{tabular}{|c|c|c|c|}
\hline Characteristic & Cases & Controls & $P$ value \\
\hline No.(\%) & $573(100)$ & $721(100)$ & \\
\hline \multicolumn{4}{|l|}{ Age, no.(\%) } \\
\hline $15-49$ y & $179(31.2)$ & $201(27.9)$ & \\
\hline $50-64$ y & $226(39.4)$ & $286(39.7$ & \\
\hline$\geq 65 y$ & $168(29.3)$ & $234(32.5)$ & 0.33 \\
\hline Mean(yr.) $\pm S D$ & $55.0 \pm 14.6$ & $56.0 \pm 15.3$ & \\
\hline Range & $15.0-90.0$ & $17.0-82.5$ & \\
\hline \multicolumn{4}{|l|}{ Sex } \\
\hline Male & $336(58.6)$ & $417(57.8)$ & \\
\hline Female & $237(41.4)$ & $304(42.2)$ & 0.77 \\
\hline \multicolumn{4}{|l|}{ NHL tumor pathology } \\
\hline All B-cell lymphoma & 451 & NA & NA \\
\hline Diffuse large B-cell & 330 & NA & NA \\
\hline Marginal zone* & 69 & NA & NA \\
\hline Follicular & 17 & NA & NA \\
\hline Mantle cell & 12 & NA & NA \\
\hline Small lymphocytic & 8 & NA & NA \\
\hline Burkitt lymphoma & 3 & NA & NA \\
\hline Others $^{B}$ & 12 & NA & NA \\
\hline All T-cell lymphoma & 122 & NA & NA \\
\hline Peripheral T-cell & 55 & NA & NA \\
\hline Others $^{\top}$ & 67 & NA & NA \\
\hline
\end{tabular}

$P$ values for differences in socio-demographic characteristics between cases and controls.

NA indicates not applicable. Marginal zone* includes marginal zone B-cell lymphoma $(n=12)$ and mucosa-associated lymphoid tissue (MALT) $(n=57)$. Others ${ }^{B}$ includes B-cell prolymphocytic leukemia $(n=1)$ and undetermined B-cell lymphoma $(n=11)$. Others ${ }^{\top}$ includes all T-cell lymphoma $(n=67)$ except for peripheral T-cell lymphoma.

\section{Genotyping}

Genomic DNA was obtained from peripheral blood using a QIAamp DNA Blood Mini Kits (Qiagen, Valencia, CA, USA) according to the manufacturer's protocols. PCR cycling and high resolution melting (HRM) analysis was performed on the Rotor-Gene $6000^{\mathrm{TM}}$ (Corbett Research, Sydney, Australia) [24]. The PCR primers were as follows: for Val762Ala (86 bp fragment), 5'-taagtcgggggctttctttt-3' (forward), and 5'-agcagactgtaggccacctc-3' (reverse); for Asp81Asp (160 bp fragment), 5'-gatgggttctctgagcttcg-3' (forward), and 5'gaggtttgctttgctctctga-3' (reverse); for Ala284Ala (76 bp fragment), 5'-gccctctgacatgtttctcc-3' (forward), and 5'-aaggagggcaccgaacac-3' (reverse); for Lys352Lys (178 bp fragment), 5'-caagggagagctggcttctt-3' (forward), and 5'-ggagttcacagcagcagga-3' (reverse); for IVS13+118A >G (124 bp fragment), 5'-tggatcaggtggcatcatag-3' (forward), and 5'-ggtactggccttcatgcaat-3' (reverse). The reaction mixture included genomic DNA (10 ng), $1 \times$ PCR buffer, $2.5 \mathrm{mM} \mathrm{MgCl} 2$, primers (100 nM), dNTPs $(100 \mu \mathrm{M})$, SYTO 9 green fluorescent nucleic acid stain $(2.5 \mu \mathrm{M}$; Invitrogen, Carlsbad, CA, USA), Taq. polymerase (0.5 U; 
Solgent, Daejeon, Korea) and water to a total volume of $10 \mu \mathrm{l}$. Cycling conditions included an initial $5 \mathrm{~min}$ hold at $95^{\circ} \mathrm{C}$, followed by 40 cycles at $95^{\circ} \mathrm{C}$ for $5 \mathrm{~s}$, annealing temperatures for $30 \mathrm{~s}$, and $72^{\circ} \mathrm{C}$ for $20 \mathrm{~s}$; a single cycle of $95^{\circ} \mathrm{C}$ for $1 \mathrm{~s}, 72^{\circ} \mathrm{C}$ for $90 \mathrm{~s}$, and melting increasing from $70^{\circ} \mathrm{C}$ to $90^{\circ} \mathrm{C}$ at $0.1^{\circ} \mathrm{C}$ per second. Annealing temperatures for Asp81Asp, Ala284Ala, Lys352Lys, Val762Ala and IVS13 $+118 \mathrm{~A}>\mathrm{G}$ were $62^{\circ} \mathrm{C}, 56^{\circ} \mathrm{C}, 58^{\circ} \mathrm{C}, 56^{\circ} \mathrm{C}$, and $60^{\circ} \mathrm{C}$, respectively.

PCR products were column-purified after HRM analysis using the PCR-M clean up kit (GeneAll Biotechnology, Seoul, Korea) according to the manufacturer's instructions. PCR products were eluted in a $20 \mu \mathrm{l}$ volume, purified PCR products were used as templates in the Big Dye Terminator v3.1 Cycling Sequencing kit (Applied Biosystems, Foster City, CA, USA). The reaction mix consisted of $1 \times$ terminator pre-mix, $1 \times$ sequencing buffer, primers (667 $\mathrm{nM})$, and purified template (1 $\mu \mathrm{l})$ in a $10 \mu \mathrm{l}$ total volume. Reactions were run on a PTC-100 thermal cycler (MJ Research, Reno, NV, USA) as follows: a single cycle of $95^{\circ} \mathrm{C}$ for $1 \mathrm{~min}, 25$ cycles of $95^{\circ} \mathrm{C}$ for $10 \mathrm{~s}, 50^{\circ} \mathrm{C}$ for $5 \mathrm{~s}$, and $60^{\circ} \mathrm{C}$ for $4 \mathrm{~min}$. Sequencing reactions were ethanol-precipitated and run on a 3100 Genetic Analyser (Applied Biosystems). In 90 subjects, the results of HRM analyses were compared with those from cycle sequencing, and the resulting concordance rate was $100 \%$.

\section{Statistical analysis}

Hardy-Weinberg equilibrium testing was performed using the chi-square goodness-of-fit test. The Pearson chi-square test was used to examine the genotype distribution differences between cases and controls. Adjusted odds ratios (ORs) were calculated using a logistic regression model that controlled for gender and age and included 95\% confidence intervals (CIs). Statistical significance was defined at $p$ values less than 0.05 , and all statistical tests were 2-sided. Haplotypes and haplotype frequencies were calculated using the SNPAnalyzer-Pro version 1.8 software (Istech, Goyang, Korea) to analyze associations between haplotypes and NHL risk after stratification by age at diagnosis, sex, and NHL subtype. All calculations were performed using an SPSS software package, version 13.0 (SPSS, Chicago, IL). PARP-1 interSNP linkage disequilibrium was calculated using Haploview software version 4.1 http://www.broad.mit.edu/ $\mathrm{mpg} /$ haploview for the set of control samples $(\mathrm{n}=721)$.

\section{Results}

Characteristics of the study population are summarized in Table 1 . There were no differences in the frequency distribution for age $(p=0.33)$ or sex $(p=0.77)$ between cases and controls. The control genotype distributions were in agreement with the Hardy-Weinberg equilibrium ( $p=0.61$ for Asp81Asp, $p=0.31$ for Ala284Ala, $p=0.83$ for Lys352Lys, $p=0.38$ for IVS13 $+118 \mathrm{~A}>\mathrm{G}, p=0.84$ for Val762Ala). Haploview version 4.1 determined that the $P A R P-1$ locus contained 1 block of linkage disequilibrium (Figure. 1). Two groups of polymorphisms were present in the block; one group consisted of Asp81Asp, Lys352Lys, and Val762Ala polymorphism, and the other included Ala284Ala and IVS13 $+118 \mathrm{~A}>\mathrm{G}$ polymorphism. Both revealed high intragroup linkage disequilibrium $\left(r^{2}, \geq 0.96\right)$, but low intergroup linkage disequilibrium $\left(\mathrm{r}^{2}, 0.22-0.23\right)$.

Table 2 summarizes the association study between the 5 polymorphisms and the overall risk for NHL. Analysis revealed no significant associations between polymorphisms and overall NHL risk. Neither the CC genotype of Val762Ala (OR, 0.85; 95\%CI, 0.62-1.17) nor the TC genotype (OR, 0.93; 95\%CI, 0.72-1.19) were associated with risk for NHL. The genotypes of the remaining 4 polymorphisms were also associated with risk for NHL.

As presented in Additional file 1: table S1, males with the TC genotype of Val762Ala demonstrated a slightly reduced NHL risk (OR, 0.84; 95\% CI, 0.60-1.16) compared to those with the TT genotype. And the males with the $\mathrm{CC}$ genotype had a significantly reduced risk (OR, 0.62; 95\% CI, 0.41-0.93) which revealed a trend toward a gene dose effect ( $\mathrm{p}$ for trend, 0.02). However, there was no association between Val762Ala polymorphism and NHL risk in females. There was significant interaction seen between sex and the Val762Ala polymorphism ( $\mathrm{p}$ for interaction, 0.048). Asp81Asp ( $\mathrm{p}$ for trend, 0.04) and Lys352Lys ( $\mathrm{p}$ for trend, 0.03) polymorphisms revealed similar trends, although interactions between sex and polymorphism were a borderline significance levels ( $\mathrm{p}$ for interaction of Asp81Asp, 0.062; $\mathrm{p}$ for interaction of Lys352Lys, 0.067). However, PARP-1 polymorphisms did not show associations with the NHL subtypes (Additional file 1: table S2) or age (data not shown).

The distribution of $P A R P-1$ haplotype frequencies and association of haplotypes with risk for NHL are summarized in Additional file 1: table S3. Three common haplotypes (ACAAC, GCGAT, and GTGGT) and several rare ones (with frequency $<5 \%$ ) were inferred, and rare haplotypes were excluded in the association analyses. None of the haplotypes were associatied with overall risk for NHL. However the haplotype-ACAAC in males was associated with decreased risk for NHL (OR, 0.74; 95\% CI, 0.59-0.94) when haplotype-GCGAT was used as a reference.

\section{Discussion}

We investigated the association between 5 PARP-1 polymorphisms and NHL risk in a Korean population. Three polymorphisms (Asp81Asp, Lys352Lys, and Val762Ala) 


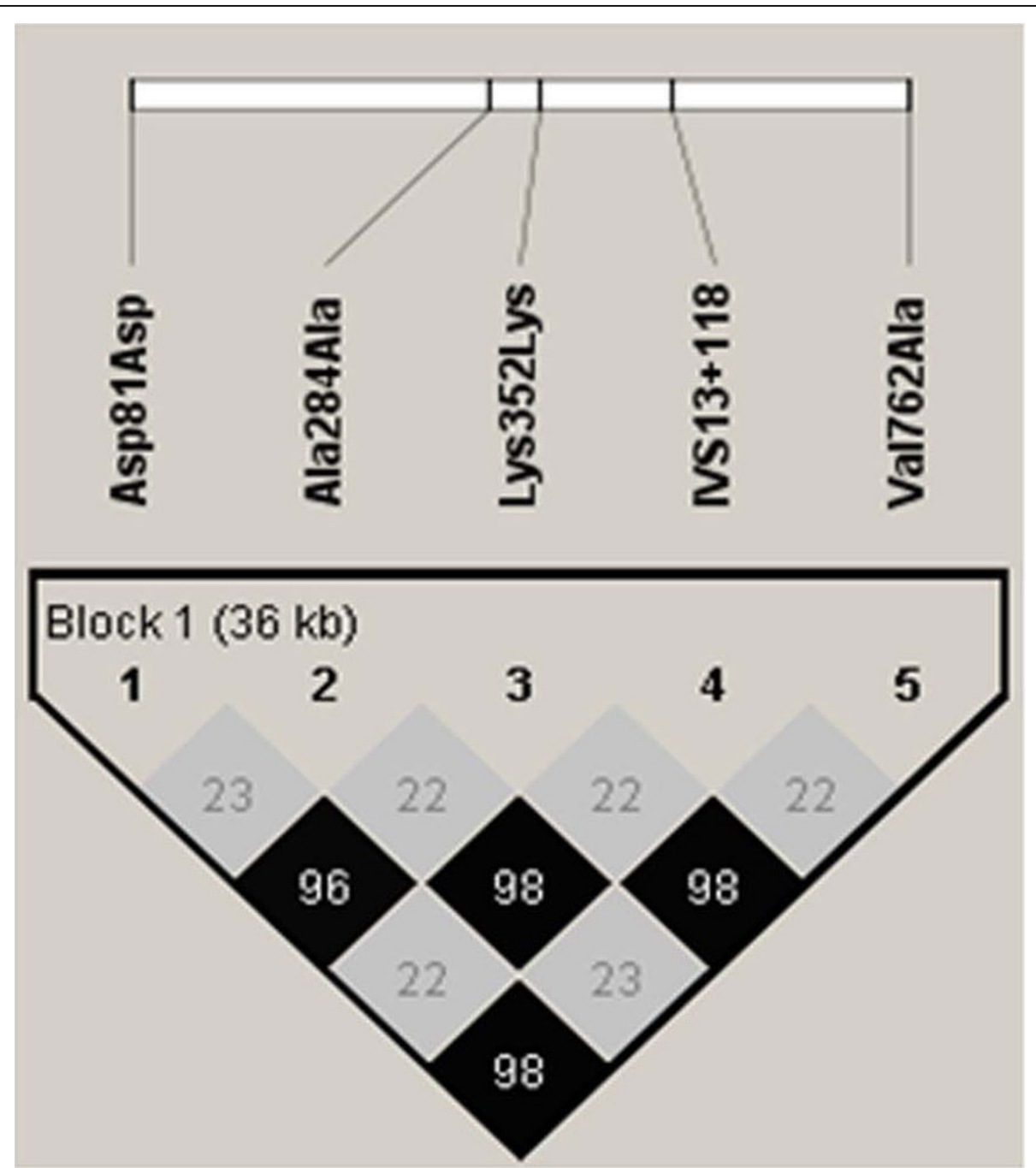

Figure 1 PARP-1 inter-polymorphism linkage disequilibrium. PARP-1 inter-polymorphism linkage disequilibrium. $r^{2}$ between pairs of polymorphisms was calculated based on all the controls using Haploview v4.1 http://www.broad.mit.edu/mpg/haploview.

were associated with decreased risk of NHL in males. A association testing of haplotype-ACAAC revealed a similar result. However, none of the $P A R P-1$ polymorphisms or haplotypes were associated with overall NHL risk.

Our data appear to support the hypothesis that accumulated DNA damage may lead to enhanced apoptosis during cell division, which could result in protection from development of malignancy with intact apoptotic mechanisms. Concordant findings with the results of this study have been identified in case-control studies of squamous cell carcinoma of the head and neck [15], breast carcinoma [18], and adult glioma [16]. In animal experiments, overexpression of dominant negative PARP-1 prevented in vivo tumor formation by HeLa cells in nude mice due to increased apoptosis of tumor cells [25].

PARP-1 polymorphisms were associated with decreased risk of NHL in males in this study. The sexual dimorphism might be associated with the female sex hormone, $17-\beta$-estradiol. PARP strongly interacts with estrogen receptor $\alpha$ and DNA in the presence of $17-\beta$-estradiol, which leads to inhibition of PARP activation [26]. Sex-dependent response to PARP activation has also been reported in an endotoxin-induced inflammation and vascular change model, female mice were more resistant to endotoxin than male mice[26]. In a neonatal-stroke mouse model, disruption of the PARP-1 gene selectively protected male mice against brain injury [27]. Also in an adult-stroke mouse model, female neuronal nitric oxide synthase knockout (nNOS-/-) mice were more severely damaged after middle cerebral artery occlusion than wild-type females. In addition, male nNOS-/- littermates were protected [28]. In a case-control study, PARP-1 polymorphism has been associated with reduced risk of adult glioma in men [16]. 
Table 2 Association testing of PARP-1 polymorphisms with risk of NHL

\begin{tabular}{|c|c|c|c|c|}
\hline$\overline{\mathrm{NPs}}$ & Genotype & $\begin{array}{l}\text { Controls } \\
\text { no.(\%) }\end{array}$ & $\begin{array}{l}\text { Cases } \\
\text { no.(\%) }\end{array}$ & OR $(95 \% \mathrm{Cl})$ \\
\hline \multirow[t]{4}{*}{ Asp81Asp } & GG & $227(31.5)$ & $185(32.5)$ & 1 \\
\hline & GA & $349(48.4)$ & $279(49.0)$ & $0.99(0.77-1.27)$ \\
\hline & $\mathrm{AA}$ & $145(20.1)$ & 105 (18.5) & $0.90(0.65-1.24)$ \\
\hline & $\mathrm{GA}+\mathrm{AA}$ & $494(68.5)$ & $384(67.5)$ & $0.96(0.76-1.21)$ \\
\hline \multirow[t]{4}{*}{ Ala284Ala } & $C C$ & $424(58.8)$ & $357(62.4)$ & 1 \\
\hline & $\mathrm{CT}$ & $264(36.6)$ & $189(33.0)$ & $0.85(0.67-1.07)$ \\
\hline & $\pi$ & $33(4.6)$ & $26(4.5)$ & $0.94(0.55-1.60)$ \\
\hline & $\mathrm{CT}+\mathrm{TT}$ & $297(41.2)$ & 215 (37.6) & $0.86(0.69-1.08)$ \\
\hline \multirow[t]{4}{*}{ Lys352Lys } & GG & $222(30.8)$ & $184(32.1)$ & 1 \\
\hline & GA & $353(49.0)$ & $285(49.7)$ & $0.98(0.76-1.26)$ \\
\hline & $\mathrm{AA}$ & $145(20.1)$ & $104(18.2)$ & $0.87(0.64-1.20)$ \\
\hline & $\mathrm{GA}+\mathrm{AA}$ & $498(69.2)$ & 389 (67.9) & $0.95(0.75-1.20)$ \\
\hline \multirow[t]{4}{*}{ IVS13+118 A>G } & $\mathrm{AA}$ & $426(59.2)$ & $361(63.0)$ & 1 \\
\hline & $A G$ & $261(36.3)$ & $188(32.8)$ & $0.85(0.67-1.07)$ \\
\hline & GG & $33(4.6)$ & $24(4.2)$ & $0.86(0.50-1.48)$ \\
\hline & $\mathrm{AG}+\mathrm{GG}$ & $294(40.8)$ & $212(37.0)$ & $0.85(0.68-1.06)$ \\
\hline \multirow[t]{4}{*}{ Val762Ala } & $\pi$ & $221(30.7)$ & $189(33.0)$ & 1 \\
\hline & $\mathrm{TC}$ & $354(49.1)$ & $279(48.7)$ & $0.93(0.72-1.19)$ \\
\hline & $C C$ & $146(20.2)$ & $105(18.3)$ & $0.85(0.62-1.17)$ \\
\hline & $\mathrm{TC}+\mathrm{CC}$ & $500(69.3)$ & $384(67.0)$ & $0.90(0.71-1.14)$ \\
\hline
\end{tabular}

All analyses have been age- and sex-adjusted. $P$ values were $>0.05$ in all analyses.

Inconsistency of the association between PARP-1 polymorphism and malignancy risk might result from differences in genetic background, environmental factors, organ specificity, and study sample size. For example, the frequency of the Val762Ala genetic polymorphism differs between ethnic groups. In the present study of Koreans, the frequency of the $\mathrm{C}$ allele is 0.448 which is consistent with that observed in previous studies of Koreans (0.444) and Han Chinese (0.389) [12,29]. However, the frequency is 0.145 in Caucasian-Americans and 0.045 among African-Americans [8]. PARP-1 expression levels vary in carcinomas of different organs. It is high in lymphoma [30] and endometrial carcinoma [31], and low in breast carcinoma [32,33] and laryngeal carcinoma [34].

In this present study, haplotype-ACAAC was also associated with reduced risk of NHL in males, although there was no association between any haplotypes and overall NHL risk. It agrees with the results that the A allele of Asp81Asp, A allele of Lys352Lys, and C allele of Val762Ala are significantly associated with decreased risk of NHL.

As the sample size of this study is not sufficiently large and is restricted to Korean population, the present data should be validated in larger samples and in other ethnic groups. Although PARP-1 polymorphisms are associated with decreased risk of NHL in the present study, we could not exclude the possibility that other un-typed variants located in or near the PARP-1 locus might be associated with reduced risk of NHL. Additional surveys examining other variants around the locus are required to resolve this issue. A gene-gene interaction study examining genes involved in apoptosis or DNA repair might allow for a more comprehensive perspective.

\section{Conclusion}

In a polulation-based, case-control study to identify the association between polymorphisms in PARP-1 and NHL risk in Koreans, we found that Val762Ala, Asp81Asp, and Lys352Lys polymorphisms and the haplotype-ACAAC in PARP-1 were associated with decreased risk of NHL in males.

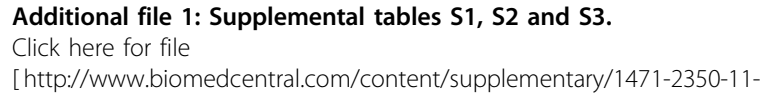

\section{Acknowledgements}

This study was supported by a grant from the Korea Health 21 R\&D Project, Ministry of Health and Welfare, Republic of Korea (01-PJ10-PG6-01GN160005).

\section{Author details}

${ }^{1}$ Genome Research Center for Hematopoietic Diseases, Chonnam National University Hwasun Hospital, 160, Ilsim-ni, Hwasun-eup, Hwasun-gun,

Chonnam, 519-809, Republic of Korea. '2Department of Pathology, Chonnam National University Medical School, 5 Hak-dong, Dong-gu, Gwangju, 501-746, Republic of Korea. ${ }^{3}$ Department of Hematology/Oncology, Chonnam National University Medical School, 5 Hak-dong, Dong-gu, Gwangju, 501-746, Republic of Korea. ${ }^{4}$ Department of Preventive Medicine, Chonnam National University Medical School, 5 Hak-dong, Dong-gu, Gwangju, 501-746, Republic of Korea. ${ }^{5}$ Department of Preventive Medicine, College of Medicine, Seonam University, 720 Gwangchi-dong, Namwon, 590-711, Republic of Korea.

\section{Authors' contributions}

All authors read and approved the final version to be published. XMJ carried out genotyping and drafted the manuscript. HNK participated in sequence alignment. IKL involved in drafting the manuscript and revising it critically. KSP did statistical analysis of the data. HJK have given final approval of the version to be published. JSC collected the control samples and advised in data analysis. SWJ designed of the study. CC designed the study and helped to draft the manuscript.

\section{Competing interests}

The authors declare that they have no competing interests.

Received: 29 September 2009 Accepted: 3 March 2010

Published: 3 March 2010

\section{References}

1. Muller AM, Ihorst G, Mertelsmann R, Engelhardt M: Epidemiology of nonHodgkin's lymphoma (NHL): trends, geographic distribution, and etiology. Ann Hematol 2005, 84:1-12. 
2. Boyle P, Levin B: World cancer report 2008. Lyon: International Agency for Research on Cancer 2008, 468-473.

3. Herceg Z, Wang ZQ: Functions of poly(ADP-ribose) polymerase (PARP) in DNA repair, genomic integrity and cell death. Mutat Res 2001, 477:97-110.

4. Lindahl T, Satoh MS, Poirier GG, Klungland A: Post-translational modification of poly(ADP-ribose) polymerase induced by DNA strand breaks. Trends Biochem Sci 1995, 20:405-411.

5. Yu SW, Wang H, Poitras MF, Coombs C, Bowers WJ, Federoff HJ, Poirier GG, Dawson TM, Dawson VL: Mediation of poly(ADP-ribose) polymerase-1dependent cell death by apoptosis-inducing factor. Science 2002, 297:259-263.

6. Figueroa JD, Malats N, Real FX, Silverman D, Kogevinas M, Chanock S, Welch R, Dosemeci M, Tardon A, Serra C, et al: Genetic variation in the base excision repair pathway and bladder cancer risk. Hum Genet 2007, 121:233-242.

7. Hao B, Wang H, Zhou K, Li Y, Chen X, Zhou G, Zhu Y, Miao X, Tan W, Wei $Q$, et al: Identification of genetic variants in base excision repair pathway and their associations with risk of esophageal squamous cell carcinoma. Cancer Res 2004, 64:4378-4384.

8. Lockett KL, Hall MC, Xu J, Zheng SL, Berwick M, Chuang SC, Clark PE, Cramer SD, Lohman K, Hu JJ: The ADPRT V762A genetic variant contributes to prostate cancer susceptibility and deficient enzyme function. Cancer Res 2004, 64:6344-6348.

9. Nozaki T, Fujihara H, Watanabe M, Tsutsumi M, Nakamoto K, Kusuoka O, Kamada N, Suzuki H, Nakagama H, Sugimura T, et al: Parp-1 deficiency implicated in colon and liver tumorigenesis induced by azoxymethane. Cancer Sci 2003, 94:497-500.

10. Tong WM, Cortes U, Hande MP, Ohgaki H, Cavalli LR, Lansdorp PM, Haddad BR, Wang ZQ: Synergistic role of Ku80 and poly(ADP-ribose) polymerase in suppressing chromosomal aberrations and liver cancer formation. Cancer Res 2002, 62:6990-6996.

11. Zhang Q, Li Y, Li X, Zhou W, Shi B, Chen H, Yuan W: PARP-1 Val762Ala polymorphism, CagA+ H. pylori infection and risk for gastric cancer in Han Chinese population. Mol Biol Rep 2009, 36:1461-1467.

12. Zhang X, Miao X, Liang G, Hao B, Wang Y, Tan W, Li Y, Guo Y, He F, Wei Q, et al: Polymorphisms in DNA base excision repair genes ADPRT and XRCC1 and risk of lung cancer. Cancer Res 2005, 65:722-726.

13. Zhang Z, Miao XP, Tan W, Guo YL, Zhang XM, Lin DX: [Correlation of genetic polymorphisms in DNA repair genes ADPRT and XRCC1 to risk of gastric cancer]. Ai Zheng 2006, 25:7-10.

14. Conde C, Mark M, Oliver FJ, Huber A, de Murcia G, Menissier-de Murcia J: Loss of poly(ADP-ribose) polymerase-1 causes increased tumour latency in p53-deficient mice. EMBO J 2001, 20:3535-3543.

15. Li C, Hu Z, Lu J, Liu Z, Wang LE, El-Naggar AK, Sturgis EM, Spitz MR, Wei Q: Genetic polymorphisms in DNA base-excision repair genes ADPRT, XRCC1, and APE1 and the risk of squamous cell carcinoma of the head and neck. Cancer 2007, 110:867-875.

16. Liu Y, Scheurer ME, El-Zein R, Cao Y, Do KA, Gilbert M, Aldape KD, Wei Q, Etzel C, Bondy ML: Association and interactions between DNA repair gene polymorphisms and adult glioma. Cancer Epidemiol Biomarkers Prev 2009, 18:204-214

17. Martin-Oliva D, O'Valle F, Munoz-Gamez JA, Valenzuela MT, Nunez MI, Aguilar M, Ruiz de Almodovar JM, Garcia del Moral R, Oliver FJ: Crosstalk between PARP-1 and NF-kappaB modulates the promotion of skin neoplasia. Oncogene 2004, 23:5275-5283.

18. Smith TR, Levine EA, Freimanis Rl, Akman SA, Allen GO, Hoang KN, LiuMares W, Hu JJ: Polygenic model of DNA repair genetic polymorphisms in human breast cancer risk. Carcinogenesis 2008, 29:2132-2138.

19. Masutani $M$, Nakagama $H$, Sugimura T: Poly(ADP-ribosyl)ation in relation to cancer and autoimmune disease. Cell Mol Life Sci 2005, 62:769-783.

20. Shen M, Zheng T, Lan Q, Zhang Y, Zahm SH, Wang SS, Holford TR, Leaderer $B$, Yeager M, Welch R, et al: Polymorphisms in DNA repair genes and risk of non-Hodgkin lymphoma among women in Connecticut. Hum Genet 2006, 119:659-668.

21. Kim HN, Kim YK, Lee IK, Lee JJ, Yang DH, Park KS, Choi JS, Park MR, Jo DY, Kim HJ: Polymorphisms involved in the folate metabolizing pathway and risk of multiple myeloma. Am J Hematol 2007, 82:798-801.

22. Jaffe ES, Harris NL, Stein H, Vardiman JW: World Health Organization classification of tumours. Pathology and genetics of tumours of hematopoietic and lymphoid tissues. Lyon: IARC Press 2001.
23. Lister TA, Crowther D, Sutcliffe SB, Glatstein E, Canellos GP, Young RC, Rosenberg SA, Coltman CA, Tubiana M: Report of a committee convened to discuss the evaluation and staging of patients with Hodgkin's disease: Cotswolds meeting. J Clin Oncol 1989, 7:1630-1636.

24. Polakova KM, Lopotova T, Klamova H, Moravcova J: High-resolution melt curve analysis: initial screening for mutations in BCR-ABL kinase domain. Leuk Res 2008, 32:1236-1243.

25. Hans MA, Muller M, Meyer-Ficca M, Burkle A, Kupper JH: Overexpression of dominant negative PARP interferes with tumor formation of HeLa cells in nude mice: evidence for increased tumor cell apoptosis in vivo. Oncogene 1999, 18:7010-7015.

26. Mabley JG, Horvath EM, Murthy KG, Zsengeller Z, Vaslin A, Benko R, Kollai M, Szabo C: Gender differences in the endotoxin-induced inflammatory and vascular responses: potential role of poly(ADP-ribose) polymerase activation. J Pharmacol Exp Ther 2005, 315:812-820

27. Hagberg H, Wilson MA, Matsushita H, Zhu C, Lange M, Gustavsson M, Poitras MF, Dawson TM, Dawson VL, Northington F, et al: PARP-1 gene disruption in mice preferentially protects males from perinatal brain injury. J Neurochem 2004, 90:1068-1075.

28. McCullough LD, Zeng Z, Blizzard KK, Debchoudhury I, Hurn PD: Ischemic nitric oxide and poly (ADP-ribose) polymerase-1 in cerebral ischemia: male toxicity, female protection. J Cereb Blood Flow Metab 2005, 25:502-512.

29. Choi JE, Park SH, Jeon HS, Kim KM, Lee GY, Park RW, Kam S, Kim IS, Kim CH, Jheon $\mathrm{SH}$, et al: No association between haplotypes of three variants (codon 81, 284, and 762) in poly(ADP-ribose) polymerase gene and risk of primary lung cancer. Cancer Epidemiol Biomarkers Prev 2003, 12:947-949.

30. Tomoda T, Kurashige T, Moriki T, Yamamoto H, Fujimoto S, Taniguchi T: Enhanced expression of poly(ADP-ribose) synthetase gene in malignant lymphoma. Am J Hematol 1991, 37:223-227.

31. Ghabreau L, Roux JP, Frappart PO, Mathevet P, Patricot LM, Mokni M, Korbi S, Wang ZQ, Tong WM, Frappart L: Poly(ADP-ribose) polymerase-1, a novel partner of progesterone receptors in endometrial cancer and its precursors. Int J Cancer 2004, 109:317-321.

32. Bieche I, de Murcia G, Lidereau R: Poly(ADP-ribose) polymerase gene expression status and genomic instability in human breast cancer. Clin Cancer Res 1996, 2:1163-1167.

33. Hu JJ, Roush GC, Dubin N, Berwick M, Roses DF, Harris MN: Poly(ADPribose) polymerase in human breast cancer: a case-control analysis. Pharmacogenetics 1997, 7:309-316.

34. Rajaee-Behbahani N, Schmezer P, Ramroth $\mathrm{H}$, Burkle A, Bartsch $\mathrm{H}$, Dietz A, Becher H: Reduced poly(ADP-ribosyl)ation in lymphocytes of laryngeal cancer patients: results of a case-control study. Int J Cancer 2002, 98:780-784.

\section{Pre-publication history}

The pre-publication history for this paper can be accessed here:http://www. biomedcentral.com/1471-2350/11/38/prepub

doi:10.1186/1471-2350-11-38

Cite this article as: Jin et al:: PARP-1 Val762Ala polymorphism is associated with reduced risk of non-Hodgkin lymphoma in Korean males. BMC Medical Genetics 2010 11:38.

\section{Submit your next manuscript to BioMed Central and take full advantage of:}

- Convenient online submission

- Thorough peer review

- No space constraints or color figure charges

- Immediate publication on acceptance

- Inclusion in PubMed, CAS, Scopus and Google Scholar

- Research which is freely available for redistribution 